\title{
A New Low-Cost Method of Harvesting Coffee in High-Yielding Plantations'
}

\author{
José Vicente-Chandler, Servando Silva, and Fernando Abruña ${ }^{2}$
}

\section{INTRODUCTION}

Coffee in Puerto Rico, as in much of the world, is harvested by going over the plantations several times during the picking season, collecting only the ripe berries which are dropped into baskets tied to the pickers' waist. In Puerto Rico, laborers are currently paid $\$ 1$ per 5 gallons of berries picked, or about 20 cents per pound of market coffee.

Many coffee plantations, intensively managed as recommended by Vincente-Chandler, Abruña, Bosque, and Silva, ${ }^{8}$ are now yielding up to 2,000 pounds of market coffee per acre. In these plantations picking costs alone approach $\$ 400$ per acre yearly.

Heavy losses result in these high-yielding plantations from berries dropping to the ground during the picking season. Silva, Vicente-Chandler, and Abruña' found that in four typical high-yielding commercial plantings, an average of 931 pounds of market coffee (worth over \$600) were lost per acre yearly in this manner.

The high cost of picking and the heavy losses of berries totalling about $\$ 1,000$ per acre yearly, combined with the increasingly acute labor shortage, suggest the need for changes in current harvesting procedures. Silva, Vicente-Chandler, and Abruña found that the efficiency and therefore, the income of pickers could be increased by about 50 percent if they had only to dislodge the ripe berries, allowing them to fall on sections of netting laid under the trees, rather than having to transfer the berries to baskets tied to the pickers' waist as at present. Losses of berries during actual picking operations, averaging 12 percent of the total crop, were prevented with this

1 This paper covers work carried out cooperatively between the Soil and Water Conservation Research Division, Agricultural Research Service, USDA, and the Agricultural Experiment Station, Mayagüez Campus, University of Puerto Rico, Río Piedras, P.R.

- Soil Scientist-Project Leader, Agricultural Technician, and Soil Scientist, respectively, Soil and Water Conservation Research Division, A.R.S., USDA, Río Piedras, P.R.

- Vicente-Chandler, J., Abruña, F., Bosque-Lugo, R., and Silva, S., Intensive Coffee Culture in Puerto Rico, Bull. 211, Agr. Expt. Str., Mayagüez Campus, Univ. P.R., 1968.

- Silva, S., Vicente-Chandler, J., and Abruña, F., Field losses of coffee and improved harvesting methods in intensively-managed plantations, J. Agr. Univ. P.R. b8 (4): 1969. 
system. Silva, Abruña, and Vicente-Chandler ${ }^{5}$ found that the number of pickings could be substantially reduced in intensively managed plantations, thus also increasing labor efficiency.

The present study relates to the harvesting of coffee in high-yielding plantations by using plastic netting permanently laid out on the ground to catch falling berries which are collected periodically for processing.

\section{MATERIALS AND METHODS}

The study was conducted in an intensively managed 7-year-old plantation of the Bourbon variety, growing in full sunlight, and yielding approximately 2,000 pounds of market coffee per acre. The trees, each with 2 or 3 vertical stems and averaging about 10 feet in height, are 4 feet apart in rows 10 feet apart. There are few weeds under the vigorously growing coffee trees, which almost completely shade the ground (fig. 1). The average slope of the land is 40 percent.

Light netting of polypropylene or polyethylene, selling at about $\$ 1$ per 100 square feet, or $\$ 400$ per acre, was used. These nettings are resistant to fertilizers and herbicides and tolerate trampling and handling well. They burn slowly if exposed to a direct flame, but are almost impossible to burn when laid out in the field.

The netting was purchased in 11-foot widths so that, when laid between the 10 -foot rows of coffee, 1 foot of screen would lay up against the downhill row of coffee to catch rolling berries (fig. 1). This precaution would not be necessary in commercial plantings entirely covered by netting, since it is immaterial where the coffee berries finally settle.

A series of tests were conducted to: 1 , Develop a practical method of collecting and processing the coffee; 2 , obtain estimates of labor and other costs involved; and 3, determine the effect of frequency of collection on the quality of coffee falling on the netting. In the latter study coffee was collected from different strips of netting at 2-, 4-, 6-, 8-, and 12-week intervals throughout the picking season. It was then processed and its quality evaluated visually and by cup tests carried out by experts at the "Nescafe" Instant Coffee plant near Manatí.

\section{RESULTS AND DISCUSSION}

Approximately 25-foot sections of 11-foot-wide netting can be conveniently handled by two men. In collecting the coffee, each man holds 2 corners of the netting, lifting the lower one first to keep the berries from rolling downhill. The netting is then gathered toward the center shaking it so that the beans and leaves collect there (fig. 2). If there is little coffee, the

'Silva, S., Abruña, F., and Vicente-Chandler, J., Effect of picking frequency on yields and quality of intensively managed coffee. J. Agr. Univ. P.R. 52 (4): 339-42, 1968. 


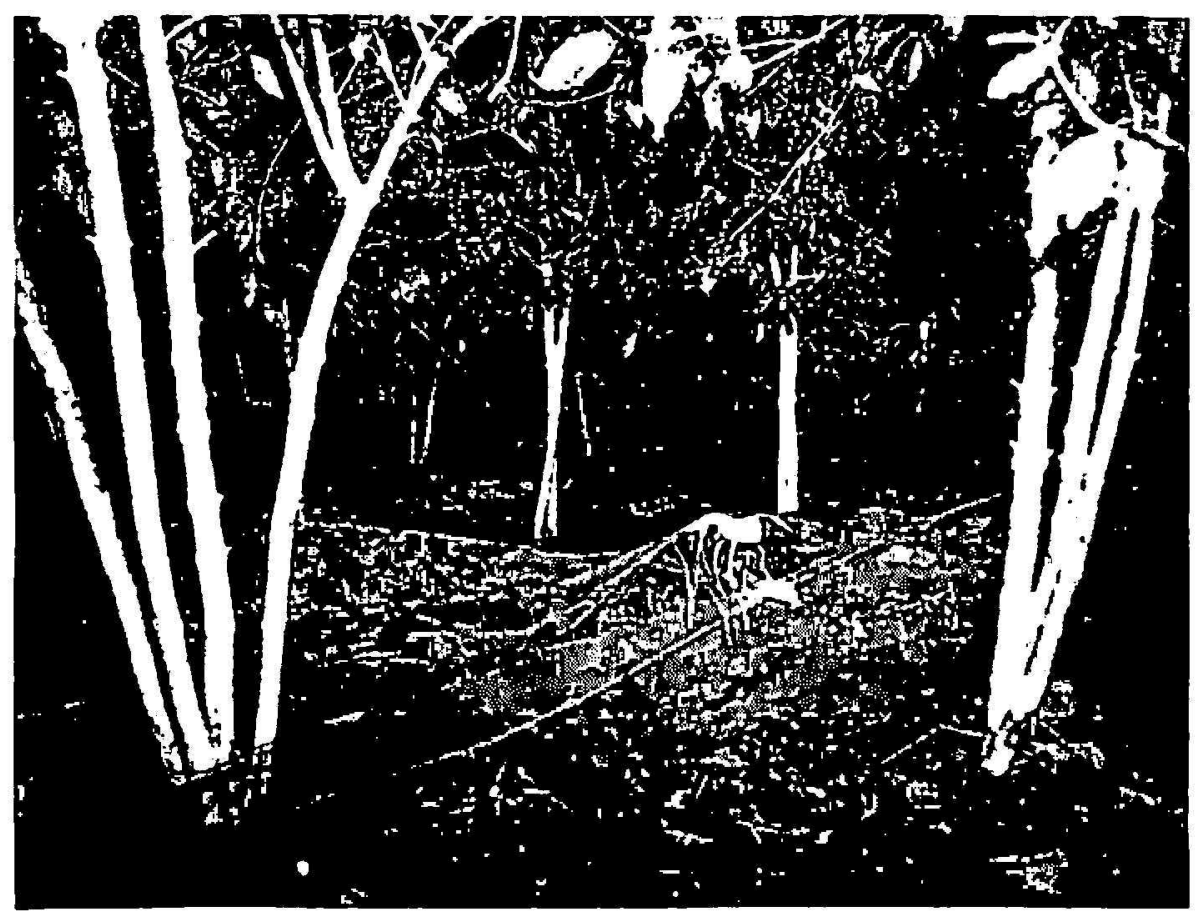

FIG. 1.-Netting laid under on intensively managed 7-year-old coffee plantation. Strips of netting cover all ground between 10 -foot coffee rows. Netting remains on ground during entire harvest season and is stored in rolls in the field or barn between seasons. Excellent results have been obtained on slopes up to 50 percent. Low-growing, unproductive coffee branches have been cut off to facilitate collection of beans. Dense shade from vigorously growing, unprumed coffee, prevents weed growth.

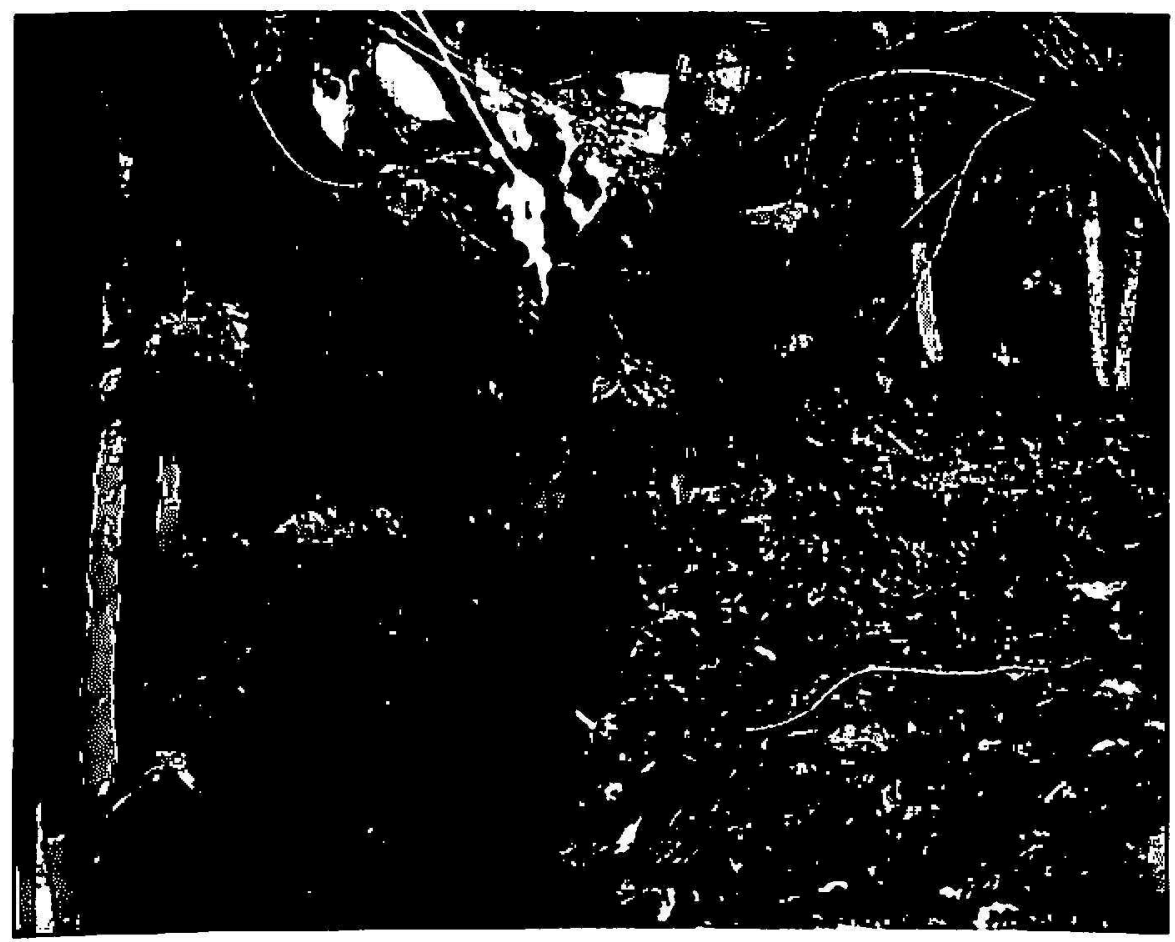

Fig. 2.-Collecting coffee beans by gathering up netting cut to 25-foot lengths for easy handling. Note mixture of beans, berries, twigs, and leaves collected on the netting. Beans should be collected about every 6 weeks. Five man-days of labor are rectuired per acre for each of + collections during the picking season. 
content of one section of netting can be dumped on to the lower one as the laborers work downhill. The netting is replaced as soon as the coffee has been collected.

When a reasonable quantity of material has been gathered on a section of netting, it is carried to a conveniently located collection point (fig. 3). A collection point is required for about every acre of coffee, so that the large volume of material is not transported far.

Material arriving at the collection points consists of a large volume of

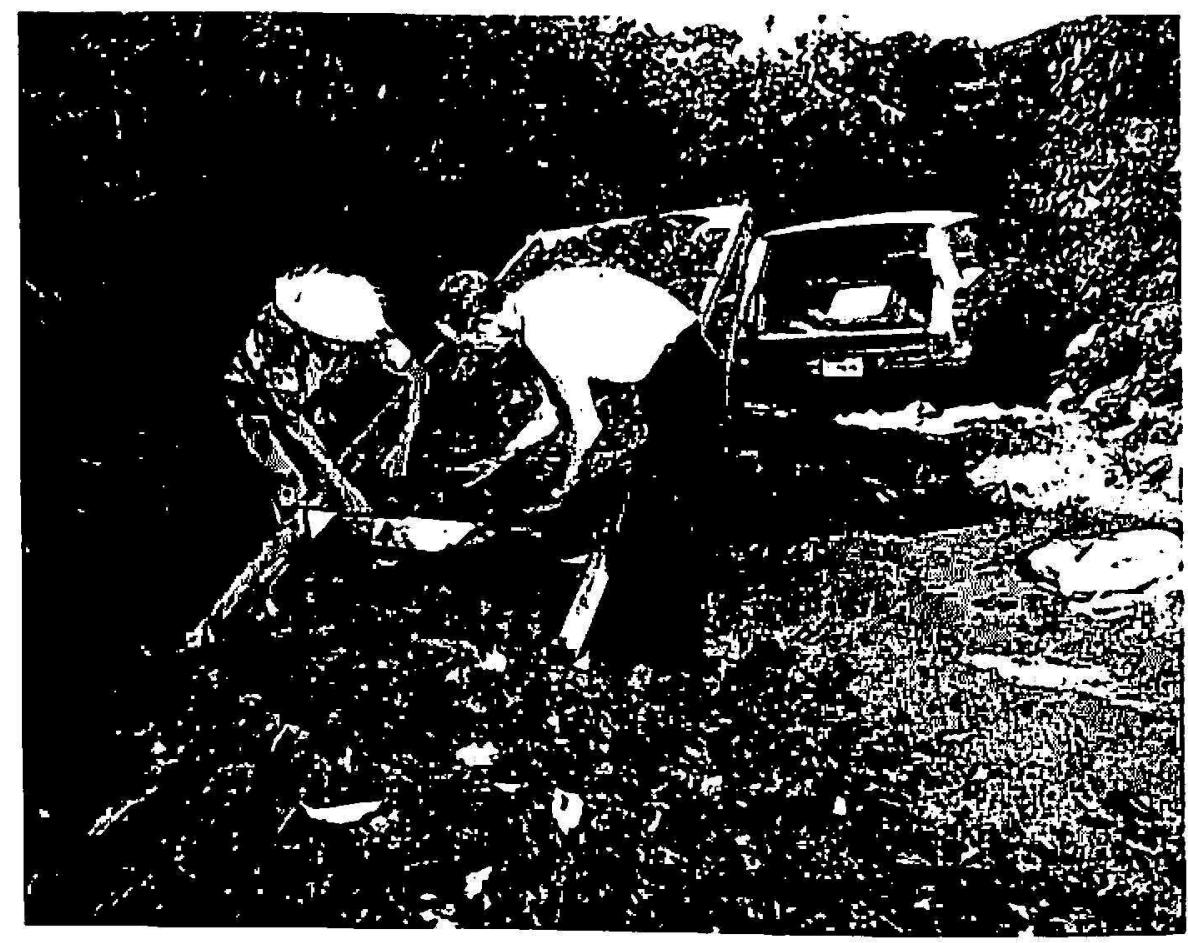

FIG. 3.-Mixture of coffee and trash collected on the netting is shaken onto a 1 -inch screen in the field to remove most of the leaves and larger twigs. At the processing center the remaining trash is removed by sieving, following by flotation in water. The beans are then washed by pumping them from one concrete tank to another with a centrifugal pump. The beans are dried in rotating drum driers. Another alternative is to dry and hull the coffee after sieving as it comes from the field.

leaves mixed with coffee beans and with some berries in various stages of fermentation (fig. 2). If the material is collected at short intervals berries predominate, but if collected at the recommended 6 -week intervals 75 percent or more of the coffee is in the form of beans (parchment coffee), the pulp having decomposed naturally.

At the collection points most of the leaves are removed by dumping the material from the netting on to a screen with 1-inch openings and then shaking by hand (fig. 3). The screen should be mounted on a frame about 4 feet $x 8$ feet, set about 2 feet above the ground. A section of netting is laid under the screen to collect the berries and beans as they fall through the 
screen (fig. 3). Since it is much easier to separate dry than wet leaves from the coffee beans, dry weather should be preferred for collection. After this initial screening, the mixture of beans and some berries in various stages of fermentation together with some leaves and twigs (fig. 3) should be transported promptly to the processing center since, if stored, the material may heat up (ferment) with a consequent loss in quality.

At the processing center the material may be further screened to remove more of the remaining leaves and twigs or dropped into a tank of water where much of the trash is removed by flotation. The coffee is then washed back and forth between two cement tanks with the help of a centrifugal pump to complete cleaning and removal of skin. The beans should then be dried in mechanical dryers and stored as parchment coffee or hulled. Another alternative is to simply sieve dry and then hull the coffee. Separation of trash by a high velocity air stream has possibilities in this respect.

Detailed cup tests showed no decrease in coffee quality with intervals between collection of 2,4 , and 6 weeks. At $S$ weeks some of the coffee beans germinated if the weather was wet. It thus seems best to collect the coffee from the nets about every 6 weeks, or 3 to 4 collections during each harvest season.

The coffee collected from the nets in all cases had as good a flavor as that processed by the "wet" method. The coffee processed by the standard "wet" method, however, was superior in appearance in the parchment stage.

The good quality of the coffee collected on the netting is easily explained. Ripe berries falling on the netting ferment and decompose naturally in the shade of the coffee trees. Since the berries are distributed on the netting they do not heat up during fermentation, which would lower the quality of the coffee. Also, few immature berries fall on the netting and those that do, rot away without affecting the quality of the remaining beans.

Netting may be left on the ground throughout the year, but it is usually best to store it in rolls in the field or barn to prevent possible damage and heavy accumulation of leaves and twigs. The netting should be laid out again when berries start ripening the following year.

The only pruning visualized with this system of harvesting coffee is that required periodically to clear walks between the coffee rows under the overhanging trees. These walks facilitate collection of the beans, fertilization, liming, and application of Disyston for leaf miner control. Pruning ordinarily required to remove branches broken by pickers is not necessary nor is drastic renovation pruning every 7 or 8 years to facilitate picking. How long unpruned, undisturbed plantations such as these will continue to bear heavily is not yet known.

With this new system of harvesting coffee, weeding also is reduced to a 
bare minimum, since the coffee trees almost totally shade the ground, virtually preventing weed growth.

Thus, management of the plantations, once they are well established, is limited to 2 or 3 fertilizer applications yearly, liming every 3 or 4 years, application of Disyston once a year, keeping walks open between rows and collecting the beans from the netting 3 or 4 times during the picking season.

\section{COSTS AND PROFITS}

Time studies showed that about 5 man-days of labor are required per acre for each collection of coffee from the netting, including removal of leaves at collection points and transportation to the processing centers. Thus, a total of 20 man-days are required per acre for harvesting (assuming 4 collections) as compared with about 66 man-days with the current system.

The following tabulation shows per acre costs and profits with the proposed new method of harvesting coffee as compared with the current

\section{Currenl method of harvesting}

(1,500 pounds of market coffee harvested per acre)

Picking (66 man-days) (333 almudes at $\$ 1.00)$.

$\$ 333.00$

Processing and marketing $(1,500$ pounds of market coffee at $\$+.00)$

60.00

Total harvesting and processing costs.

393.00

Other costs of productiont

Total costs per acre

767.00

Income per acre $\{1,100$ pounds at 68 cents $\}$

$\left\{400\right.$ pounds at 64 cents $\left.^{a}\right\}$

1004.00

Net profit per acre

237.00

Net profit per 100 pounds of market coffee................. 15.80

New melhorl of harvesting

$(2,300$ pounds of market coffee harvested per acre)

Collection (20 man-days at $\$ 8.00$.

$\$ 1(60.00$

138.00

16.00

80.00

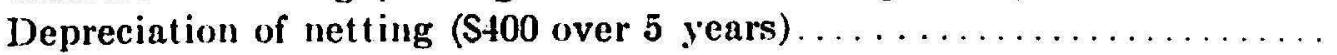

394.00

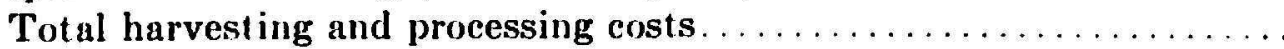

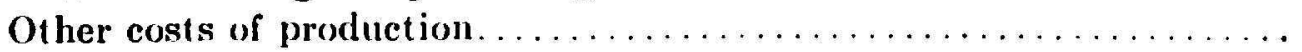

Total costs per acre . . . . . . . . . . . . . . . . . . . . . .

Income per acre $(2,300$ pounds at $\$ 64.00)$

482.00

876.00

Net profit per acre.

$1,472.00$

596.00

Net profit per hundred pounds of market coffee $\ldots \ldots \ldots \ldots \ldots \ldots$

25.91

- Data taken from Bull. 202 “Intensive Coffee Culture in Puerto Rico, by José Vicente-Chandler, Fernando Abruña, Ramón Bosque Lugo, and Servando Silva., Agr. Expt. Sta., Mayagüez Campus, Univ. P. R. 
method. Harvested yields of 2,300 pounds of market coffee per acre are assumed with the new system as compared with 1,500 pounds with the current system, which results in about one-third of the crop being lost because of berries dropping to the ground, as shown by Silva, Vicente-Chandler, and Abruña. ${ }^{6}$ Wages of $\$ 8$ and $\$ 4$ daily are assumed for all labor with the new and current systems, respectively.

This tabulation shows that the proposed new method of harvesting coffee, even with wages of $\$ 8$ daily for all labor, results in a net profit of $\$ 596$ per acre, or $\$ 25.91$ per 100 pounds of market coffee, as compared with $\$ 237$ per acre, or $\$ 15.80$ per hundredweight, for the current system with wages of only $\$ 4$ daily. With wages of $\$ 8$ daily the current system would be uneconomical to farmers. Further savings with the new system, not taken into account in the tabulation, include reduced pruning and weeding costs as discussed previously.

\section{OTHER ADVANTAGES AND DISADVANTAGES OF THIS METHOD}

Other advantages of this new system of harvesting coffee in high yielding intensively managed plantations are:

1. Only 20 man-days of labor are required per acre yearly in harvesting, compared with about 66 man-days with the current system. This increase in labor efficiency permits payment of higher wages.

2. Labor requirements are much more evenly distributed throughout the year and the picking season. A 20-acre plantation, for example, would require about 4 laborers during the picking season and 2 during the remainder of the year. With the current system such a plantation requires an average of about 15 laborers during the picking season (as many as 20 during peak periods) and only 2 during the remainder of the year.

3. To a considerable extent, coffee can be harvested when convenient, i.e., during clear weather, when labor is available, when machinery is operating efficiently, etc.

4. The coffee trees are not damaged during picking operations as occurs with the current system.

On the other hand, some of the disadvantages of the new system for harvesting coffee are:

1. The main disadvantage of this new system is the initial investment in netting of about $\$ 400$ per acre. This investment can be attenuated by direct Government subsidies.

2. This new method of harvesting coffee can be used only in properly laid-out, high-yielding plantations.

- Ibid., Silva, S., Vicente-Chandler, J., and Abruña, F., p. 4. 
3. Coffee produced is usually of a quality equivalent to Brazilian "Santos" coffee on the world market. Price of this coffee in both the world and Puerto Rico markets is approximately 4 cents per pound lower than for "washed" coffees.

4. Processing facilities will have to be modified somewhat to remove leaves and twigs, etc. On the other hand, facilities will not be required for pulping coffee.

\section{IMPLICATIONS OF THIS NEW METHOD OF HARVESTING FOR PUERTO RICO'S COFFEE INDUSTRY}

Average plantations producing about 200 pounds of market coffee per acre, are unprofitable, even at present wages of $\$ 4$ per day. The relatively few intensively managed plantations producing about 1,500 pounds of market coffee per acre currently yield a net profit of approximately $\$ 200$ per acre. However, with wages of $\$ 8$ per day (a reasonable goal for 1975) even such plantations would yield little or no profit at current coffee prices. Furthermore, it is unlikely that the heavy seasonal demands for pickers can be met in 1975 since scarcity of labor is already a serious problem.

On the other hand, the proposed new system of harvesting, combined with intensive management practices to produce 2,300 pounds or so of harvested market coffee per acre, would yield a net profit of over $\$ 500$ per acre with wages of $\$ 8$ per day. Seasonal fluctuations in demand for labor would also be much less, as discussed previously.

With this system only about 20,000 acres of coffee would be required to meet the Island's needs, plus a modest surplus for export, thus releasing about 120,000 acres now in coffee for other uses. A labor force of about 2,000 could be employed in these plantations throughout the year, with an additional 2,000 required during the harvest season. The latter could easily be employed in other farm enterprises during the remainder of the year. Thus, a well-paid labor force of about 4,000 could be employed throughout the year on coffee farms.

This stable employment on coffee farms, plus that in related industries such as processing, distribution, and sale, are a strong inducement for continuing to maintain a reasonable price support for coffee. Furthermore, about $\$ 14$ million would be drained from the economy yearly to purchase coffee on the world market, should the local industry disappear, as it may well do if it continues to be neglected.

The proposed highly profitable plantations concentrated on a limited acreage of accessible land can probably be readily rehabilitated following a hurricane. On the other hand, farmers are not likely to rehabilitate the current unprofitable plantings after such a disaster.

Some advantages of this system of collecting coffee over methods being tested in other countries and which involve shaking the trees and catching 
the falling berries are:

1. Losses from fruit-drop (worth over $\$ 600$ per acre in Puerto Rico) occurring mostly between pickings are almost totally recovered with the net method.

2. Severe, repeated pruning required for mechanical picking sharply decrease yields. Little pruning is required with the net method.

3. Only mature beans are harvested with the net method. Many green berries are shaken off the trees with the proposed mechanical methods. Hormone sprays to control ripening or fruit drop may some day be used to obviate this problem.

4. The net system works well on steep lands where mechanization is otherwise difficult.

5. No machinery is required with the net method, a distinct advantage in the Tropics, and intervals between collections are much more flexible.

\section{SUMMARY}

A new, simple method for harvesting coffee in intensively managed, highyielding plantations is described. Long-lasting plastic netting is laid between coffee rows. Berries dropping on the netting are collected about every 6 weeks and processed by a simple modification of the current system. Quality of the coffee produced is equivalent to that of Brazilian "Santos".

This new method reduces labor requirements for harvesting to less than one-third, and increases yields of harvested coffee by over 50 percent as compared with the current system, by reducing field losses of coffee. Net profit is increased $2 \frac{1}{2}$ times to over $\$ 500$ per acre yearly with wages of $\$ 8$ daily. Cost of the netting is $\$ 400$ per acre. Government credit or subsidies are suggested to help defray this initial cost.

\section{RESUMEN}

En este estudio se describe un nuevo método para cosechar café en plantaciones de alta producción cultivadas intensivamente. Se tienden mallas de plástico entre las hileras de café y cada 6 semanas se recoge, aproximadamente, el café que cae en las mallas y se beneficia mediante una modification sencilla en el método corriente. La calidad del café así cosechado es equivalente al "Santos" de Brazil.

Este nuevo método reduce la mano de obra en la cosecha a menos de un tercio y aumenta la cantidad de café cosechado en más del 50 porciento en comparación con el sistema actual, al reducirse las pérdidas en el campo. El ingreso neto por cuerda se aumenta $21 / 2$ veces, para un total de más de $\$ 500$ anualmente, pagándose salarios de $\$ 8$ diarios. El costo de la malla asciende a $\$ 400$ por cuerda. Se sugiere el pago de un incentivo o la extensión de un crédito por parte del Gobierno para ayudar a sufragar el costo inicial. 